\title{
Makroekonomik Faktörler ve Pay Senedi Getirisi: BIST Banka Endeksi Firmaları Üzerine Panel Veri Analizi
}

\author{
Emre Esat TOPALOĞLU* \\ Özlem KARAKOZAK ${ }^{* *}$
}

\section{ÖZET}

Çalışmada, makroekonomik faktörler olarak ifade edilen döviz kuru, faiz oranı, enflasyon oranı, altın fiyatı ve para arzı ile pay senedi getirisi arasındaki ilişsiyi ortaya çıkarmak amaçlanmıştır. Bu amaçla çalışmada, 2007: 12-2017: 9 dönemleri arasında Borsa İstanbul Banka Endeksi'nde pay senetleri işlem gören bankalar analiz kapsamında incelenmiştir. Makroekonomik faktörler, TL/USD alış ve satış ortalaması, mevduatlara uygulanan ağırlıklı ortalama faiz oranı, yurt içi üretici fiyat endeksi, 1 ons altın Londra satış fiyatı ve M2 esas alınarak belirlenirken, pay senedi getirisi ise sürekli geometrik getiri ile ölçülmüş̧ür. Pay senedi getirisi ile makroekonomik faktörler arasındaki ilişki panel veri analizi kullanılarak araştırılmuştır. Araştırma neticesinde, pay senedi getirisi ile döviz kuru, faiz oranı ve para arzı arasında istatistiksel olarak anlamlı ve negatif yönlü ilişki tespit edilirken, altın fiyatı ve enflasyon oranı ile pay senedi getirisi arasında herhangi bir ilişki tespit edilmemiştir.

Anahtar Kelimeler: Pay Senedi Getirisi, Makroekonomik Faktörler, Panel Veri Analizi, Borsa Istanbul, Banka Endeksi.

JEL Sinıflandırması: G12, G20, G32.

Macroeconomic Factors and Stock Returns: Panel Data Analysis on BIST Banks Index Firms

\section{ABSTRACT}

This study aims to reveal the relationship between exchange rate, interest rate, inflation rate, gold price and money supply, which are expressed as macroeconomic factors and the stock return. For this purpose, the study was conducted within the framework of the analysis of the banks whose shares are traded in the Stock Exchange Istanbul Bank Index between 2007: 12-2017: 9. Macroeconomic factors were measured based on TL / USD buying and selling averages, weighted average interest rates applied to deposits, domestic producer price index, 1 ounce gold London sales price and M2, while the yield of shares was measured by continuous geometric yield. The relationship between stock return and macroeconomic factors was explored using panel data analysis. As a result of the research, statistically significant and negative relationship was observed between exchange rate, interest rate and money supply and the stock return. On the other hand there was no significant relationship between the price of gold and inflation rate and the stock return. Index.

Keywords: Stock Return, Macroeconomic Factors, Panel Data Analysis, Borsa Istanbul, Banks

Jel Classification: G12, G20, G32.

\footnotetext{
* Yrd. Doç. Dr. Emre Esat Topaloğlu, Şırnak Üniversitesi, İktisadi ve İdari Bilimler Fakültesi, İşletme Bölümü, emresatopal@hotmail.com

** Öğr. Gör. Özlem Karakozak, Nevşehir Hacı Bektaş Veli Üniversitesi, ozkara86@gmail.com
} 


\section{GİRIŞ}

Geçmişten günümüze pay senedi fiyatları ya da getirileri ile makroekonomik değişkenlerin ilişkisi büyük ilgi çekmektedir. Pay senedi getirilerinin farklı ekonomik göstergelerden etkilenip etkilenmediği, etkilendiyse hangi yönde ve düzeyde gerçekleştiği finans yazınında bu konunun sürekli güncel kalmasını sağlamıştır.

Özellikle günümüzde firmalarda finansın fon sağlama veya bulma şeklindeki geleneksel görüşü terkedilerek firmanın değer yaratan unsurları bir bütün olarak değerlendirilmektedir. Bu sayede firmanın içsel ve dişsal bütün etki ve potansiyellerinin tek bir alana kanalize edilmesiyle finans, hissedarlar açısından firmanın piyasa değerini maksimum kılma amacına yönelmiştir.

Genel olarak finans yazınında pay senedi getirisini etkileyen unsurlar firma içi faktörler ve firma dışı faktörler olmak üzere iki başlık altında incelenmektedir. İçsel faktör olarak yatırılan sermayeden elde edilen getiriyi; satışlar, kar marjı, işletme sermayesinin etkin yönetimi, sabit sermaye yatırımları ve ağırlıklı ortalama sermaye maliyeti olarak sıralanabilir (Ercan ve Ban, 2005: 338). Firmanın dişsal potansiyellerini etkileyen satın alma ve satma işlemlerinin yanı sıra makroekonomik faktörlerde meydana gelen değişmelerin ve gelişmelerin etkisiyle de pay senedi getirilerinin artması ya da azalması şeklindeki eğilimlerin firmanın piyasa değerini büyük oranda etkilediği düşünülmektedir (Errunza ve Senbet,1981; Palia ve Thomas, 1997; Lesseig ve Stock, 1998; Beaulieu, vd., 2002; Ünal ve Altın, 2010; Çam, 2014; Flota, 2014).

Finans yazını dikkate alınarak yapılan bu çalışmada ise gelişmekte olan ülke konumundaki Türkiye'nin finansal istikrarı için önemli bir yeri olan bankacılık sektöründe faaliyet gösteren bankaların pay senedi getirileri ile makroekonomik faktörler arasındaki ilişki, 2007: 12-2017: 9 3'er aylık dönemler itibariyle araştırılmıştır. Çalışmada, bağımlı değişken olarak pay senetleri Borsa İstanbul (BIST) Banka Endeksi'nde işlem gören bankaların pay senedi getirileri kullanılırken, bankaların pay senedi getirileri üzerinde etkisinin araştırıldığı döviz kuru, faiz oranı, enflasyon, altın fiyatı ve para arzı da bağımsız değişkenler olarak analize dâhil edilmiştir. İlerleyen bölümde değinilen ulusal ve uluslararası yazın dikkate alındığında gerçekleştirilen bu çalışma, kullanılan değişkenler, incelenen dönem ve bankacılık sektörünü ele alması açısından alan yazınına katkı sağladığı düşünülmektedir.

\section{YAZIN TARAMASI}

Türkiye'de ve yurtdışında daha önce yapılmış olan çalışmalar incelendiğinde; makroekonomik değişkenler ile pay senetleri fiyatları veya getirileri arasındaki ilişkilerin farklı yöntemler kullanılarak incelendiği görülmektedir. Bu çalışma, literatür baz alınarak belirlenen makroekonomik değişkenlerin banka pay senedi getirilerine etkisinin belirlenmesi yönüyle finans yazınına katkı sağlamaktadır.

Makroekonomik değişkenlerin pay senedi getirileri üzerine olan etkisinin araştırıldığı çalışmalar incelendiğinde;

Dizdarlar ve Derindere (2008) çalışmasında, İMKB-100 pay senedi endeksi üzerinde etkisi olan makroekonomik değişkenleri belirlemeyi amaçlamıştır. 2005-2007 dönemi için 
yapılan analiz sonucunda döviz kurunun İMKB-100 endeksini negatif yönde etkilediği sonucuna varılmıştır.

Boztosun (2010) çalışmasında, 2002-2009 döneminde İMKB'de işlem gören bankacılık endeksindeki bankaların aylık getirilerinin makroekonomik değişkenlere karşı duyarlılığını en küçük kareler yöntemi ile analiz etmiştir. Analiz sonucunda bankalara ait pay senedi getirileri ile mevduat faiz oranı ve portföy yatırımları arasında negatif ilişki mevcutken diğer açıklayıcı değişkenlerle pozitif anlamlı ilişki olduğu sonucuna ulaşmıştır.

Sayılgan ve Süslü (2011), çalışmasında gelişmekte olan ülkelerdeki makroekonomik faktörlerin pay senedi getirilerine etkisini dengeli panel veri analizi ile 1999-2006 dönemi için araştırmıştır. Analiz sonuçları, çalışma kapsamındaki gelişmekte olan ülkelerdeki pay senedi getirileri ile; döviz kuru, enflasyon oranı ve Standart and Poors 500 endeksi ile anlamlı bir ilişki bulurken, faiz oranı, gayri safi yurtiçi hâsıla, para arzı ve petrol fiyatları ile pay senedi getirileri arasında istatistiksel olarak anlamlı bir ilişki olmadığı sonucuna varılmıştır.

Yurttançıkmaz (2012) çalışmasında, 1994-2010 dönemleri arasında makroekonomik değişkenlerin pay senedi getirileri üzerindeki etkilerini zaman serisi analizi ve Granger nedensellik testi uygulayarak test etmiştir. Analiz sonucunda pay senedi getirileri üzerinde enflasyonun oldukça yüksek düzeyde ve pozitif yönlü bir etkisi olduğu buna karş1lık döviz kurlarının ise düşük düzeyli ve negatif yönlü bir etkisi olduğu sonucuna varmıştır.

Kaya v.d. (2013) çalışmasında, İMKB 100 Endeksi ile bazı makroekonomik değişkenler arasındaki ilişkiyi çoklu regresyon modeli en küçük kareler tahmin yöntemi ile incelemiştir. 2002-2012 dönemlerini kapsayan çalışmada edilen sonuçlara göre, pay senedi getirileri ile para arzı (M2) arasında pozitif yönlü, döviz kuru ile negatif yönlü bir ilişki olduğu tespit edilmiştir.

Arbitraj fiyatlama modeli kullanılarak pay senedi getirilerinin makroekonomik değişkenlerden etkilenme düzeyini belirlemeye çalışan bir diğer çalışma Sevinç (2014) tarafından yapılmıştır. Çalışmada Bist-30 endeksi 2003-2013 dönemleri arasında incelenmiştir. Analiz sonucunda makroekonomik değişkenlerin pay senedi getirileri üzerinde anlamlı bir etkiye sahip olduğu ve Arbitraj Fiyatlama Modeli kullanılarak pay senedi getirilerinin belirlenebileceği sonucuna varılmıştır.

Pay senedi getirileri ve makroekonomik değişkenler arasındaki ilişkiyi Hindistan'ın gelişmekte olan pazarı için araştıran Nisha (2015) çalışmasında, zaman serileri analizini kullanarak Makroekonomik değişkenlerin Bombay Menkul Kıymetler Borsası'nda (BSE) pay senedi getirilerine etkisini belirlemek için Vektör Otegresyon (VAR) kullanılmıştır. Analiz sonucunda, faiz oranının, altın fiyatının, döviz kurunun ve BSE üzerinde önemli bir etkisinin olduğu sonucuna varılmaktadır.

Çetin ve Bitırak (2015) çalışmasında, Arbitraj Fiyatlama Modeli kullanarak Türkiye'deki makroekonomik değişkenlerin pay senedi getirileri üzerine etkisini belirlemeye çalışmıştır. 2000-2009 dönemi IMKB-100 pay senedi getirilerinin kullanıldığı çalışma sonucunda IMKB-100 endeksinde işlem gören işletmelerin pay senedi getirilerinin altın fiyatlarından ve tasarruf mevduatı faiz oranından negatif yönde etkilendiği, geniş tanımlı para arzı ile imalat sanayi kapasite kullanım oranından ise pozitif yönde etkilendiği belirlenmiştir. 
Cari işlemler dengesinin, dar tanımlı para arzının ve imalat sanayi üretim endeksinin pay senedi getirileri üzerindeki etkisi ise istatistiksel olarak anlamlı bulunmamıştır.

Acar Boyacıoğlu ve Çürük (2016) çalışmasında, döviz kurundaki değişimlerin pay senedi getirisi üzerindeki etkisini araştırmıştır. Çalışmada Borsa İstanbul 100 Endeksi'nde 2006-2014 y1lları arasında işlem gören imalat ve ticaret sektörlerinde faaliyet gösteren 42 firma getirilerine panel veri analizi uygulanmıştır. Çalışmanın sonucunda, reel döviz kuru endeksindeki değişimin pay senedi getirisi üzerinde pozitif anlamlı etkisinin olduğu sonucuna varılmıştır.

Pay senedi getirileri ile döviz kurları arasındaki ilişkiyi araştıran bir diğer çalışma Belen ve Karamelikli (2016) aittir. Çalışmada ARDL eşbütünleşme yaklaşımı kullanılarak yapılan analiz sonucunda döviz kurunun pay senedi getirilerini beklentiye paralel olarak negatif yönde etkilediğini göstermektedir. Sonuçlar ayrıca para arzının da beklentilere uygun olarak pay senedi fiyatlarını pozitif yönde etkilediğini göstermektedir.

Makroekonomik değişkenlerin pay senedi fiyatları üzerine olan etkisinin araştırıldığı çalışmalar incelendiğinde;

Albeni ve Demir (2005) çalışmasında, IMKB fiyat endekslerinden mali endeks hisse senetleri kullanılmıştır. Uygulamada mali endeks pay senedi fiyatları ile makroekonomik değişkenler arasındaki ilişkiyi belirleyebilmek adına çok değişkenli doğrusal regresyon modeli kullanılmıştır. Araştırma sonucunda mali sektör pay senedi fiyatlarını etkileyen makro ekonomik değişkenler mevduat faiz oranları, cumhuriyet altını, uluslararası portföy yatırımları ve Alman Markı olarak belirlenmiştir.

Humpe ve Macmillan (2007) çalışmasında, 1965-2005 dönemleri için ABD ve Japonya hisse senetleri fiyatlarının makroekonomik değişkenlerden etkilenme düzeyini belirlemeye çalışmıştır. Analiz sonucunda, ABD hisse sentleri fiyatının endüstriyel üretim ile pozitif yönde, uzun vadeli faiz oranı, tüketici fiyat endeksiyle negatif yönde ilişkili olduğu belirlenmiştir. Japonya pay senedi fiyatlarının ise endüstriyel üretim ve para arzı ile negatif yönde ilişkili olduğu sonucuna varılmıştır.

Özer v.d. (2011) çalışmasında, 1996-2009 dönemi İMKB 100 Endeksi ile bazı makroekonomik değişkenler arasında bir ilişki olup olmadığı En Küçük Kareler Yöntemi, Johansen-Juselius Eşbütünleşme Testi, Granger Nedensellik Testi ve VEC modelleri belirlenmeye çalışılmıştır. Araştırma sonucuna göre; pay senedi fiyatı ile tüketici fiyat indeksi, faiz oranı, para arzı, diş ticaret dengesi ve sanayi üretim endeksi değişkenleri arasında uzun dönemli bir ilişki bulunmuştur.

Güngör ve Kaygın (2015) çalışmasında, pay senedi fiyatlarının gelecekteki yönünü tahmin edebilmek adına hem mikroekonomik faktörler hem de makroekonomik faktörlerin pay senedi fiyat hareketlerini etkileme gücünü belirlemeye çalışmıştır. Borsa İstanbul'da 2005-2011 dönemi imalat sanayi işletmelerinin finansal verileri ile belirlenen makroekonomik değişkenler Dinamik Panel Veri Analizi ile test edilmiştir. Çalışma dönemi boyunca döviz kuru, para arzı, petrol fiyatları ve sanayi üretim endeksi ile pay senedi fiyatı arasında pozitif yönlü bir ilişki belirlenirken, enflasyon oranı, faiz oranı, GSYİH, altın fiyatları ve dış ticaret dengesi ile pay senedi fiyatı arasında negatif yönlü bir ilişki belirlenmiştir. 


\section{METODOLOJİ}

Çalışmada, mali sektörde faaliyet gösteren ve Borsa İstanbul Banka Endeksi'nde pay senetleri işlem gören bankaların pay senedi getirilerine etki eden makroekonomik faktörleri panel veri analiz yöntemi kullanarak tespit etmek amaçlanmıştır. 2007: 12-2017: 9 dönemleri arasında BIST Banka Endeksi'nde işlem gören 13 banka çalışma kapsamına dâhil edilmiştir. Çalışmada, incelenen bankalar, Tablo 1'de gösterilmektedir.

Tablo 1. Analize Dâhil Edilen Bankalar

\begin{tabular}{crl}
\hline $\begin{array}{c}\text { Sıra } \\
\text { No }\end{array}$ & Firma Adı & BIST KODU \\
\hline 1 & Akbank & AKBNK \\
2 & Albaraka Türk Katılım Bankası & ALBRK \\
3 & Denizbank & DENIZ \\
4 & Finansbank & FINBN \\
5 & ICBC Turkey Bank & ICBCT \\
6 & Şekerbank & SKBNK \\
7 & Türkiye Garanti Bankası & GARAN \\
8 & Türkiye Halk Bankası & HALKB \\
9 & Türkiye İş Bankası (C) & ISCTR \\
10 & Türkiye Kalkınma Bankası & KLNMA \\
11 & Türkiye Sinai Kalkınma Bankası & TSKB \\
12 & Türkiye Vakıflar Bankası & VAKBN \\
13 & Yapı ve Kredi Bankası & YKBNK \\
\hline & Kaynak: www.kap.org.tr &
\end{tabular}

Modelde kullanılan değişkenler, Borsa İstanbul (www.borsaistanbul.com) ve Merkez Bankas1 (www.tcmb.gov.tr) web sitelerinden elde edilmiştir. Tablo 2'de analizde kullanılan değişkenler ve hesaplama şekilleri sunulmaktadır.

Tablo 2. Değişkenler ve Hesaplama Şekilleri

\begin{tabular}{|c|c|c|}
\hline Bağımlı Değişken & Pay Senedi Getirisi & Ln $\left(Y_{t} / Y_{t-1}\right)$ Sürekli Geometrik Getiri \\
\hline \multirow{5}{*}{ Bağımsız Değişken } & Döviz Kuru & $\begin{array}{l}\text { Kurlar-Döviz Kurları (Günlük) (TL dönüşümü } \\
\text { yapılmış) TL/USD Alış ve Satış Ortalama }\end{array}$ \\
\hline & Faiz Oranı & $\begin{array}{l}\text { Bankalarca Açılan Mevduatlara Uygulanan } \\
\text { Ağırlıklı Ortalama Faiz Oranları (Akım Veriler, \%) }\end{array}$ \\
\hline & Enflasyon & Yurt İçi Üretici Fiyat Endeksi \\
\hline & Altın Fiyatı & $\begin{array}{l}1 \text { Ons Altın Londra Satış Fiyatı (ABD Doları/Ons) } \\
\text { Altın Fiyatları \% Değişim (Ortalama)-Serbest } \\
\text { Piyasa }\end{array}$ \\
\hline & Para Arzı & $\begin{array}{l}\text { M2 = M1 (Dolaşımdaki Para + Vadesiz Mevduat) }+ \\
\text { Vadeli Mevduat (TL, YP) }\end{array}$ \\
\hline
\end{tabular}


Çalışmada kullanılan makroekonomik faktörlerde incelenen dönem içerisinde gerçekleşen değişimler diğer bir deyiş̧le zaman serilerinin yapılarına ilişkin zaman yolu grafikleri aşağıdaki Şekil 1'de gösterilmektedir.

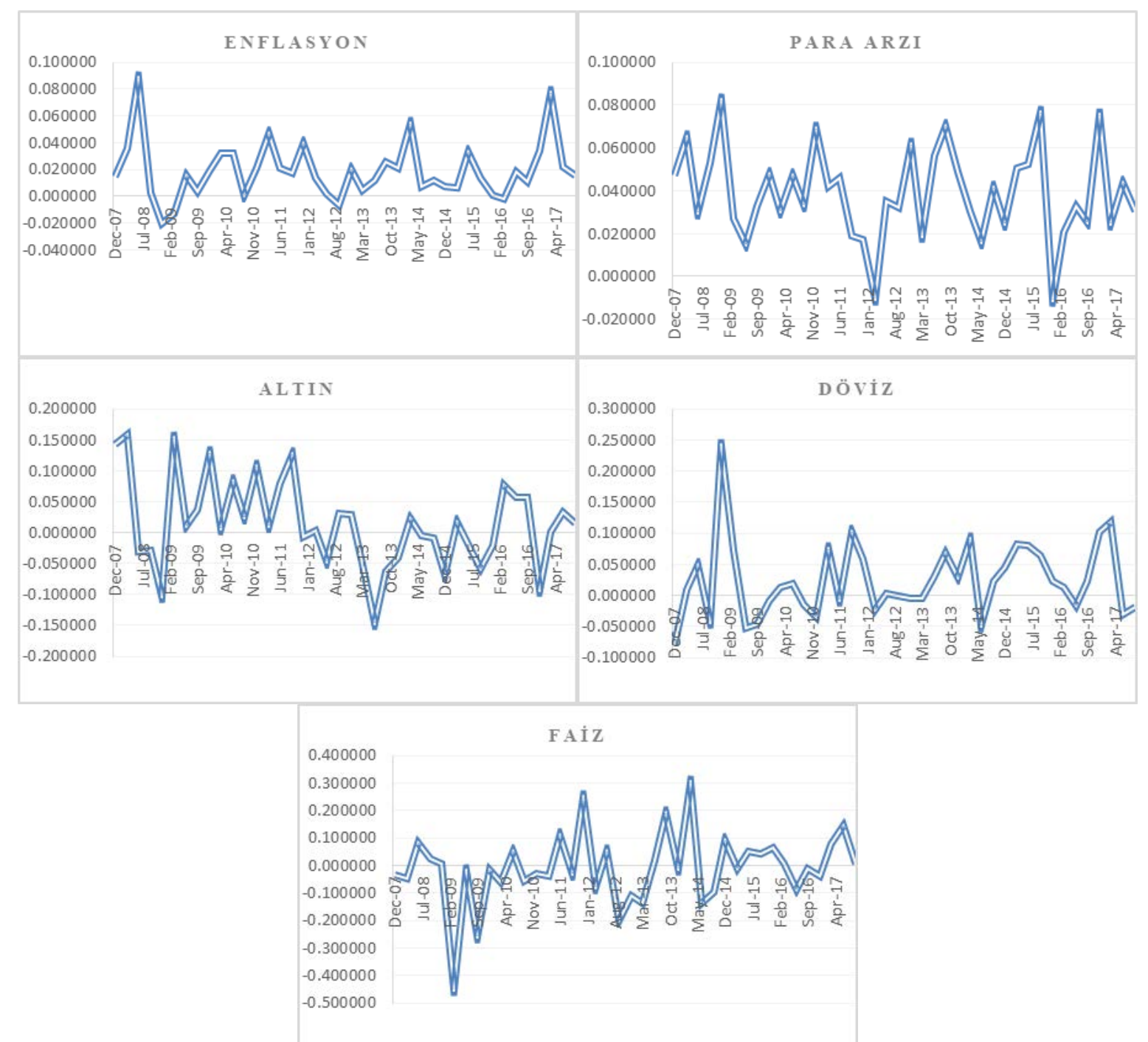

Şekil 1. Makroekonomik Faktörlere İlişkin Zaman Grafikleri

Şekil 1 incelendiğinde, döviz, enflasyon oranı, para arzı, faiz oranları ve altın fiyatlarına ilişkin zaman serilerinde dalgalanmalar gözlemlenmektedir.

Bağımsız değişkenler arasında çoklu doğrusal bağlantı sorununun olup olmadığına ilişkin olarak, Spearman korelasyon analizi gerçekleştirilmiş ve VIF değerleri hesaplanmıştır. Tablo 3'te çalışmada kullanılan değişkenlere ilişkin korelasyon analiz sonuçları sunulmaktadır. 
Tablo 3. Korelasyon Analiz Sonuçları

\begin{tabular}{|c|c|c|c|c|c|c|}
\hline $\begin{array}{l}\text { Korelasyon } \\
\text { t-İstatistiği } \\
\text { Olasılık }\end{array}$ & GET & ALT & DOV & ENF & FAIZ & PARZ \\
\hline GET & $\begin{array}{r}1.000000 \\
---- \\
----\end{array}$ & & & & & \\
\hline ALT & $\begin{array}{r}0.106369 \\
2.434737 \\
0.0152\end{array}$ & $\begin{array}{r}1.000000 \\
----- \\
----\end{array}$ & & & & \\
\hline DOV & $\begin{array}{r}-0.415579 \\
-10.39892 \\
0.0000\end{array}$ & $\begin{array}{r}-0.351782 \\
-8.553131 \\
0.0000\end{array}$ & $\begin{array}{r}1.000000 \\
----- \\
----\end{array}$ & & & \\
\hline ENF & $\begin{array}{r}-0.144173 \\
-3.315965 \\
0.0010\end{array}$ & $\begin{array}{r}0.059099 \\
1.347436 \\
0.1784\end{array}$ & $\begin{array}{r}0.248405 \\
5.836547 \\
0.0000\end{array}$ & $\begin{array}{r}1.000000 \\
----- \\
----\end{array}$ & & \\
\hline FAIZ & $\begin{array}{r}-0.195183 \\
-4.529416 \\
0.0000\end{array}$ & $\begin{array}{r}-0.301689 \\
-7.201875 \\
0.0000\end{array}$ & $\begin{array}{r}0.330019 \\
7.956889 \\
0.0000\end{array}$ & $\begin{array}{r}0.363227 \\
8.872921 \\
0.0000\end{array}$ & $\begin{array}{r}1.000000 \\
-----\end{array}$ & \\
\hline PARZ & $\begin{array}{r}-0.287151 \\
-6.822777 \\
0.0000\end{array}$ & $\begin{array}{r}-0.105066 \\
-2.404563 \\
0.0165\end{array}$ & $\begin{array}{r}0.147467 \\
3.393396 \\
0.0007\end{array}$ & $\begin{array}{r}0.160976 \\
3.712155 \\
0.0002\end{array}$ & $\begin{array}{r}0.075985 \\
1.734403 \\
0.0834\end{array}$ & $\begin{array}{r}1.000000 \\
---- \\
---\end{array}$ \\
\hline
\end{tabular}

Korelasyon analizinde iki değişken arasında \%75'in üzerinde ilişki tespit edilen değişkenlerin analizden çıkarılması önerilmektedir (Albayrak, 2005: 105-107). Korelasyon analiz sonuçları incelendiğinde bağımsız değişkenler arasında kritik değer \%75'in üzerinde herhangi bir ilişki tespit edilmemiştir. Dolayısıyla analizde kullanılan bağımsız değişkenler arasında çoklu doğrusal bağlantı problemi söz konusu değildir.

Spearman korelasyon analizinin yanı sıra, değişkenler arasında çoklu doğrusal bağlantı sorununun olup olmadiğına ilişkin Varyans Enflasyon Faktörü (VIF) analizi de yapılabilmektedir. VIF değerlerinin 10'dan daha düşük bir değer alması, bağımsız değişkenler arasında çoklu doğrusal bağlantı sorununun olmadığına işaret etmektedir (Gujarati, 1995). VIF analiz sonuçları Tablo 4'te gösterilmektedir. 
Tablo 4. VIF Değerleri

\begin{tabular}{rccc}
\hline Değişken & $\begin{array}{c}\text { Varyans } \\
\text { Katsayısı }\end{array}$ & $\begin{array}{c}\text { Uncentered } \\
\text { VIF }\end{array}$ & $\begin{array}{c}\text { Centered } \\
\text { VIF }\end{array}$ \\
\hline ALT & 0.016225 & 1.316772 & 1.254869 \\
DOV & 0.022781 & 1.482645 & 1.256093 \\
ENF & 0.195907 & 2.460109 & 1.358955 \\
FAIZ & 0.005715 & 1.482557 & 1.474761 \\
PARZ & 0.157585 & 4.814287 & 1.095406 \\
$\mathbf{C}$ & 0.000368 & 5.770332 & NA \\
\hline Not 1: Tabloda; Pay Senedi Getirisi (GET), Altın Fiyatı (ALT), \\
Döviz Kuru (DOV), Enflasyon Oranı (ENF), Faiz Oranı (FAIZ) \\
ve Para Arzı (PARZ) ile gösterilmektedir. \\
\hline \multicolumn{4}{l}{} \\
\hline
\end{tabular}

Tablo 4'te sunulan VIF değerleri incelendiğinde bağımsız değişkenlere ait değerlerin kritik değerin altında olduğu ve dolayısıyla çoklu doğrusal bağlantı sorununun olmadığı görülmektedir. Bu bulgu, korelasyon analiz sonuçlarını destekler niteliktedir.

Tablo 5. Tanımlayıcı İstatistik Analiz Sonuçları

\begin{tabular}{lcccccc}
\hline & GET & ALT & DOV & ENF & FAIZ & PARZ \\
\hline Ortalama & 0.0176 & 0.0155 & 0.0251 & 0.0189 & -0.0093 & 0.0387 \\
Medyan & 0.0056 & 0.0111 & 0.0167 & 0.0154 & -0.0111 & 0.0342 \\
Maksimum & 0.7752 & 0.1592 & 0.2414 & 0.0881 & 0.3043 & 0.0819 \\
Minimum & -1.0185 & -0.1466 & -0.0789 & -0.0203 & -0.4516 & -0.0107 \\
Std. Sap. & 0.2061 & 0.0702 & 0.0593 & 0.0210 & 0.1283 & 0.0210 \\
Çarp1klık & -0.0283 & 0.1688 & 1.1243 & 1.2352 & -0.6010 & -0.0624 \\
Basıklık & 5.4381 & 2.7569 & 5.4076 & 5.2753 & 5.6718 & 2.9852 \\
Jarque-Bera & 128.87 & 3.7493 & 235.15 & 244.41 & 185.98 & 0.3422 \\
Probability & 0.0000 & 0.1534 & 0.0000 & 0.0000 & 0.0000 & 0.8427 \\
Gözlem & 520 & 520 & 520 & 520 & 520 & 520 \\
\hline
\end{tabular}

Tablo 5'te çalışmada kullanılan değişkenlere ilişkin ortalama, medyan, maksimum, minimum, standart sapma, normal dağılım, çarpıklık ve basıklık istatistikleri yer almaktadır. Ortalama değerler incelendiğinde, 2007: 12-2017: 9 döneminde pay senedi getirileri \%1,76 altın fiyatının \%1,55, döviz kurunun \%2,5, enflasyon oranının \%1,89, faiz oranının -\%093, para arzının \%3,87 olduğu tespit edilmişstir. Standart sapma açısından değişkenlere ilişkin istatistik değerler dikkate alındığında, faiz oranları ve pay senedi getirilerinde değişkenliğin daha fazla olduğu söylenebilir.

Çalışmada, makroekonomik faktörlerin endeks getirisine olan etkisini ortaya çıkarabilmek için kurgulanan model aşağıda gösterilmektedir.

$\mathrm{Get}_{i t}=\beta_{\mathrm{it}}+\beta_{1 \mathrm{it}} \mathrm{ALT}_{\mathrm{it}}+\beta_{2 \mathrm{it}} \mathrm{DOV}_{\mathrm{it}}+\beta_{3 \mathrm{it}} \mathrm{ENF}_{\mathrm{it}}+\beta_{4 \mathrm{it}} \mathrm{FAIZ}_{\mathrm{it}}+\beta_{5 \mathrm{it}} \mathrm{PARZ}_{\mathrm{it}}+\mathrm{u}_{\mathrm{it}}$

Denklemde, $\mathrm{i}=1,2,3, \ldots . . \mathrm{N}$ yatay kesit birimlerini ifade ederken, $\mathrm{t}=1,2,3, \ldots . \mathrm{T}$ zaman boyutunu, u ise panel hata terimini ifade etmektedir.

Çalışma kapsamında oluşturulan modelde yer alan bağımsız değişkenlerin bağımlı değişkeni etkileme yönlerine ilişkin beklentiler, Tablo 6'da gösterilmektedir. 
Tablo 6. Bağımlı Değişken İle Bağımsız Değişkenler Arasında Beklenen İlişki

\begin{tabular}{rc}
\hline Bağımsız Değişken & Beklenen İlişkinin Yönü \\
\hline TL/USD Alış ve Satış Ortalama \% Değişim \\
Faiz Oranı \\
Mevduatlara Uygulanan Ağırlıklı Ortalama Faiz Oranları \\
Enflasyon Oranı & Negatif \\
Yurt İçi Üretici Fiyat Endeksi & Negatif \\
Altın Fiyatı & Negatif \\
ABD Doları/Ons & Negatif \\
Para Arzı & Pozitif \\
M2 &
\end{tabular}

Döviz kuru, faiz oran1, enflasyon oran1, altın fiyatı ve para arzı ile endeks getirisi arasında negatif ilişki beklenirken, para arzı ile endeks getirisi arasında ise pozitif ilişkinin varlığı beklenmektedir. Para arzındaki değissimler, finansal piyasaları doğrudan etkilemektedir. Para arzındaki artış, piyasadaki fon miktarının artmasına yol açmakta diğer bir deyişle, kredi olarak verilecek olan para miktarında fazlalık söz konusu olacaktır. Bu durum da piyasa faiz oranlarını düşme eğilimine girecektir. Para arzındaki artış, bankaların daha fazla faaliyette bulunmasına imkân tanımakta ve ekonomik olarak büyümeye yol açabilmektedir. Bu etkiler de bankaların pay senedi getirilerini pozitif yönde etkilemektedir.

Enflasyon oranındaki artış ise yerel paranın yabancı para karşısındaki değerini düşürmekte ve ekonomik bozulmaya yol açmaktadır. Bu durum da bankaların pay senedi getirilerine negatif yönde etkilemektedir. Döviz kurundaki artış firmaların nakit akışlarının bugünkü değerlerini azaltmakta, finansal durumun bozulmasına sebep olmakta ve pay senedi getirisini düşürmektedir. Faiz oranları, önemli bir makroekonomik gösterge olmakla birlikte pay senetlerinin yakın ikamesi konumundadır. Faiz oranlarının artması, repo ve hazine bonosu getirilerini artırırken, uzun vadede pay senetlerine olan yatırımların azalmasına ve pay senedi getirilerinin de düşmesine neden olabilmektedir. Pay senedi yatırımlarına alternatif bir yatırım aracı olarak görülen altın yatırımcılar açısından istikrarlı, güvenilir ve değer koruma aracı olarak nitelendirilebilmektedir. Altına olan yatırımların artması, pay senetlerine olan yatırımları azaltabilmektedir. Dolayısıyla pay senetleri ile altın fiyatları arasında negatif yönlü ilişkiden bahsedilebilir.

Çalışmada kullanılacak değişkenlerin belirlenmesi ve modelin oluşturulmasının ardından, panel veri analizi doğrultusunda yatay kesit bağımlılığı, homojenlik ve durağanlık varsayımlarının yanı sıra tahmin modelinin seçimi, otokorelasyon ve değişen varyans sorunlarının olup olmadığı tespit edilmiştir.

Yatay kesit bağımlılığının göz önünde bulundurulmadığı analiz sonuçları, sapmalı ve tutarsız hale gelebilmektedir. Seriler arasında yatay kesit bağımlılı̆̆ının varlı̆̆ı, BreuschPagan (1980) LM testi, Pesaran (2004) CD ve CDlm testleri veya Pesaran, Ullah ve Yagamata (2008) LMadj testi ile tespit edilebilmektedir.

Paneli oluşturan birimler arasında yatay kesit bağımlılığının varlığı, Gauss kodları yardımıyla panel bazında incelenmiştir. Tablo 7'de panel geneli için yapılan yatay kesit bağımlılığı analiz sonuçları verilmektedir. 
Tablo 7. Yatay Kesit Bağımlıı̆̆g Test Sonuçları

\begin{tabular}{lcc}
\hline \multicolumn{1}{c}{ CD Testleri } & İstatistik & Olasılık Değeri \\
\hline$C D_{l m}$ (BP,1980) & 764.704 & 0.000 \\
$C D_{l m}$ (Pesaran, 2004) & 54.980 & 0.000 \\
$C D \quad$ (Pesaran, 2004) & 22.179 & 0.000 \\
$L M_{\text {adj }}$ (PUY, 2008) & 56.698 & 0.000 \\
\hline
\end{tabular}

$\mathrm{H}_{0}$ : Kesitler arasında bağımlılık yoktur

$\mathrm{H}_{1}$ : Kesitler arasında bağımlılık vardır.

Panel bazında yatay kesit bağımlılı̆̆ (YKB) testlerine ilişkin sonuçlar incelendiğinde, YKB için gerçekleştirilen bütün testlerde olasılık değerinin 0.05 'ten küçük çıktığı tespit edilmiştir. Çalışmanın zaman ve kesit boyutu doğrultusunda, YKB için Pesaran CDlm (2004) test sonuçları dikkate alınmıştır. Dolayısıyla sıfır hipotez olan "kesitler arasında bağımlılık yoktur" reddedilmektedir. Diğer bir deyişle paneli oluşturan kesitler arasında yatay kesit bağımlılığı söz konusudur. Bu doğrultuda çalışmada, serilerin durağanlık sınaması için ikincil nesil birim kök testleri kullanılmıştır.

Panel veri analizi kapsamında sınanması gereken bir diğer varsayım panel ve değişken bazında ayrı ayrı gerçekleştirilen homojenlik sınamasıdır. Panel bazında homojenlik testi ile sabit terimin ve eğim katsayılarının her bir ülke için homojen mi yoksa heterojen mi olduğu tespit edilebilmektedir. Homojenlik sınaması için Pesaran ve Yamagata (2008) delta testlerinden faydalanılmaktadır. Tablo 8'de delta test sonuçları yer almaktadır.

Tablo 8. Panel ve Değişken Bazında Homojenlik Test Sonuçları

\begin{tabular}{lcccc}
\hline Değişken & Delta_tilde & Olasılık Değeri & Düzeltilmiş Delta_tilde & Olasılık Değeri \\
\hline $\boldsymbol{\alpha}$ (Sabit Terim) & -1.882 & 0.970 & -2.066 & 0.981 \\
$\boldsymbol{\beta}$ ALT & 0.189 & 0.425 & 0.196 & 0.422 \\
$\boldsymbol{\beta}$ DOV & -0.558 & 0.712 & -0.580 & 0.719 \\
$\boldsymbol{\beta}$ ENF & -2.084 & 0.981 & -2.260 & 0.988 \\
$\boldsymbol{\beta}$ FAIZ & -1.487 & 0.931 & -1.567 & 0.941 \\
$\boldsymbol{\beta}$ PARZ & -1.835 & 0.967 & -1.961 & 0.975 \\
GET & 1.022 & 0.153 & 1.063 & 0.144 \\
ALT & -2.414 & 0.992 & -2.509 & 0.994 \\
DOV & -2.463 & 0.993 & 2.561 & 0.995 \\
ENF & -2.430 & 0.992 & -2.527 & 0.994 \\
FAIZ & -2.536 & 0.994 & -2.637 & 0.996 \\
PARZ & -2.532 & 0.994 & -2.632 & 0.996 \\
\hline
\end{tabular}

$\mathrm{H}_{0}$ : Homojenlik vardır.

$\mathrm{H}_{1}$ : Homojenlik yoktur.

Panel ve değişken bazında gerçekleştirilen homojenlik test sonuçları incelendiğinde, sabit terim, her bir değişkenin eğim katsayıları ve değişkenlerin homojenliğine ilişkin yapılan delta testi sonuçlarına göre, sabit terim, eğim katsayıları ve değişkenlerin olasılık değerlerinin kritik değerden yüksek olduğu tespit edilmiş ve sıfır hipotezi reddedilememiştir. Diğer bir ifadeyle sabit terimin ve her bir değişkenin eğim katsayılarının homojen olduğu belirlenmiştir. 
Panel veri analizini gerçekleştirebilmek ve doğru sonuçlar elde edebilmek için değişkenlere ilişkin zaman serilerinin durağanlığının sağlanması gerekmektedir (Gujarati, 2003). YKB içeren serilerin durağanlıkları, ikincil nesil birim kök testleri ile sınanmaktadır. Çalışmada durağanlık, Smith vd. (2004) Boostrap ikincil nesil birim kök testi ile sınanmıştır. Birim kök analiz sonuçları, Tablo 9'da sunulmaktadır.

Tablo 9. Smith vd. (2004) Boostrap Birim Kök Testi Sonuçları

\begin{tabular}{|c|c|c|c|c|}
\hline & \multicolumn{2}{|c|}{ Sabit } & \multicolumn{2}{|c|}{ Sabit ve Trend } \\
\hline & İstatistik & $\begin{array}{c}\text { Bootstrap } \\
\text { p-değeri }\end{array}$ & İstatistik & $\begin{array}{c}\text { Bootstrap } \\
\text { p-değeri }\end{array}$ \\
\hline \multicolumn{5}{|l|}{ GET } \\
\hline$t$-bar & -5.042 & 0.000 & -5.332 & 0.000 \\
\hline WS & -4.847 & 0.000 & -4.874 & 0.000 \\
\hline \multicolumn{5}{|l|}{ ALT } \\
\hline$t$-bar & -1.358 & 0.566 & -1.817 & 0.599 \\
\hline WS & -1.703 & 0.257 & -2.109 & 0.449 \\
\hline \multicolumn{5}{|l|}{ DOV } \\
\hline$t$-bar & -5.110 & 0.000 & -5.088 & 0.000 \\
\hline WS & -4.878 & 0.000 & -5.131 & 0.000 \\
\hline \multicolumn{5}{|l|}{ ENF } \\
\hline$t$-bar & -4.541 & 0.000 & -4.491 & 0.000 \\
\hline WS & -4.692 & 0.000 & -4.719 & 0.000 \\
\hline \multicolumn{5}{|l|}{ FAIZ } \\
\hline$t$-bar & -3.124 & 0.033 & -3.414 & 0.057 \\
\hline WS & -3.364 & 0.007 & -3.704 & 0.016 \\
\hline \multicolumn{5}{|l|}{ PARZ } \\
\hline$t-b a r$ & -4.769 & 0.000 & -4.631 & 0.000 \\
\hline WS & -4.562 & 0.000 & -4.635 & 0.000 \\
\hline \multicolumn{5}{|c|}{ Birinci Fark } \\
\hline \multicolumn{5}{|l|}{ ALT } \\
\hline$t$-bar & -6.813 & 0.000 & -6.673 & 0.000 \\
\hline WS & -5.663 & 0.000 & -5.523 & 0.000 \\
\hline
\end{tabular}

Maksimum gecikme uzunluğu 5 olarak alınmış ve optimal gecikme uzunlukları genelden özele (general-to-specific) yaklaşımı ile belirlenmiştir.

Olasılık değerleri 1000 bootstrap dağılımından elde edilmiştir.

H0: Birim kök vardır.

H1: Birim kök yoktur.

Birim kök testi neticesinde, sabitli ve sabitli/trendli modellerin her ikisinde de GET, FAIZ, DOV, ENF ve PARZ değişkenlerinin düzeyde I(0) durağan oldukları tespit edilmiştir. ALT değişkenine ilişkin serinin ise birinci dereceden farkı alınarak I(1) düzeyinde durağan olduğu belirlenmiştir.

Pay senedi getirilerine etki eden makroekonomik faktörlerin belirlenebilmesi için hangi modelin kullanılması gerektiği F testi ile tespit edilmiştir. Analiz sonuçları Tablo 10'da yer almaktadır. 
Tablo 10. F Testi Sonuçları

\begin{tabular}{lrrr}
\hline Test & İstatistik & d.f. & Prob. \\
\hline $\mathrm{F}$ & 0.204795 & $(12,489)$ & 0.9982 \\
Chi-square & 2.541626 & 12 & 0.9980 \\
\hline
\end{tabular}

Modelin, havuzlanmış model ya da sabit etkiler modeli ile tahmin edilip edilmeyeceği için gerçekleştirilen $\mathrm{F}$ testi sonuçları değerlendirildiğinde olasılık değerinin kritik değerin üzerinde olduğu belirlenmiş ve sıfır hipotezi reddedilememiştir. Dolayısıyla modelin havuzlanmış model ile tahmin edilmesi gerekmektedir.

Panel veri analizinde tutarlı ve doğru tahminleme gerçekleştirebilmek için serilerde otokorelasyon ve değișen varyans probleminin varlığı, Breusch-Godfrey LM ve Harvey testleri ile analiz edilmiştir. Analiz sonuçları Tablo 11'de yer almaktadır.

Tablo 11. Otokorelasyon ve Değişen Varyans Test Sonuçları

\begin{tabular}{|c|c|c|c|}
\hline \multirow{4}{*}{ Breusch-Godfrey LM Testi } & \multirow{4}{*}{ (Otokorelasyon) } & Obs*R-squared & 18.294 \\
\hline & & F-statistic & 3.7121 \\
\hline & & Prob. F(5,508) & 0.0026 \\
\hline & & Prob. Chi-Square(5) & 0.0026 \\
\hline \multirow{3}{*}{ Harvey Testi } & \multirow{3}{*}{ (Değişen Varyans) } & Prob. F(5,513) & 0.0155 \\
\hline & & Prob. Chi-Square(5) & 0.0159 \\
\hline & & Prob. Chi-Square(5) & 0.0100 \\
\hline
\end{tabular}

Seriler arasında otokorelasyon sorununun olup olmadığına ilişkin olarak yapılan Breusch-Godfrey LM testi sonuçlarına göre Prob F değeri kritik değer olan 0.05 'ten küçük olduğu için, "otokorelasyon yoktur" boş hipotezi reddedilmektedir. Dolayısıyla serilerde otokorelasyon sorunu söz konusudur. Değişen varyans için gerçekleştirilen Harvey testi sonucuna göre ise Prob değeri 0.015 olarak hesaplanmıştır. Bu doğrultuda Prob değeri kritik değer olan 0.05 'ten küçüktür ve serilerde değişen varyans sorununun olduğu da tespit edilmiştir.

Modelin tahmin edilme aşamasında değişen varyans ve/veya otokorelasyon sorunlarından birinin bulunması halinde tahmin edilmiş genelleştirilmiş en küçük kareler yönteminin (EGLS) veya Uygulanabilir Genelleştirilmiş En Küçük Kareler (FGSL) yönteminin kullanılması daha uygundur (Baum, 2006: 159). Modelde otokorelasyon ve değişen varyans sorunlarının varlığı tespit edilmiştir. Pooled OLS doğrultusunda otokorelasyon ve değişen varyans sorunları White'ın yatay kesit kovaryans katsayısı yöntemi (White's cross section coefficient covariance method) ile standart hataların düzeltilmesi yoluyla giderilmeye çalışılmıştır. Bu metot, yatay kesitler arasındaki farklı hata varyanslarının yanı sıra korelasyon sorununa da çözüm sunmaktadır (Korkmaz vd., 2010: 102). Tablo 12'de Pooled OLS tahmin sonuçları sunulmaktadır. 
Tablo 12. Panel EGLS analiz sonuçları

\begin{tabular}{|c|c|c|c|c|c|c|}
\hline & ALT & DöV & ENF & FAì & PARZ & Sabit \\
\hline Katsayı Tahmini & 0.0247 & -1.2946 & -0.2358 & -0.0767 & -1.7689 & 0.1258 \\
\hline Std. Hata & 0.0868 & 0.1305 & 0.3788 & 0.0457 & 0.3481 & 0.0149 \\
\hline t-İstatistik & 0.2853 & -9.9159 & -0.6224 & -1.6783 & -5.0804 & 8.4182 \\
\hline Olasılık & 0.7755 & $0.0000^{* * *}$ & 0.5339 & $0.0939^{*}$ & $0.0000^{* * *}$ & $0.0000^{* * *}$ \\
\hline F-istatistik & \multicolumn{2}{|c|}{28.32350} & \multicolumn{2}{|l|}{$\mathrm{R}^{2}$} & \multicolumn{2}{|c|}{0.220376} \\
\hline Prob(F-istatistik) & \multicolumn{2}{|c|}{$0.0000^{* * *}$} & \multicolumn{2}{|c|}{ Periyot } & \multicolumn{2}{|c|}{40} \\
\hline Metot & \multicolumn{2}{|c|}{ Pooled OLS } & \multicolumn{2}{|c|}{ Yatay Kesit } & \multicolumn{2}{|c|}{13} \\
\hline Panel Gözlem Sayısı & \multicolumn{2}{|c|}{507} & \multicolumn{2}{|c|}{ Gözlem Sayısı } & \multicolumn{2}{|c|}{520} \\
\hline
\end{tabular}

Pay senedi getirisini etkileyen makroekonomik faktörlerin belirlenmesi için gerçekleştirilen panel veri analiz sonuçları incelendiğinde, pay senedi getirisi esas alınarak oluşturulmuş modelin $\mathrm{F}$ istatistiği olasılık değerinin \%99 güven aralığında anlamlı olduğu belirlenmiştir. Modelde bağımsız değişken konumunda olan makroekonomik faktörler, bağımlı değişken konumunda olan pay senedi getirisindeki değişimlerin \%22'sini açıkladığı tespit edilmiştir. Pooled OLS analizi neticesinde elde edilen bulgular değerlendirildiğinde, döviz kuru ile pay senedi getirisi arasında istatistiksel olarak anlamlı ve beklenildiği gibi negatif ilişki tespit edilmiştir. Döviz kurundaki \%1'lik değişim bankaların pay senedi getirilerinde \%1,29'luk azalışa sebep olmaktadır. Çalışmada elde edilen bu bulgu, Dizdarlar ve Derindere (2008), Sayılgan ve Süslü (2011), ve Kaya v.d. (2013) tarafindan gerçekleştirilen çalışmalarda elde edilen bulgular ile benzerlik göstermektedir.

Faiz oranı ile pay senedi getirisi arasında $\% 90$ güven aralığında anlamlı ve beklenildiği gibi negatif ilişki belirlenmiştir. Bankaların mevduat faiz oranlarındaki \%1'lik değişim, pay senedi getirilerinde \%0,0767'lik azalışa neden olmaktadır. Ulaşılan bu bulgu, Boztosun (2010), Sevinç (2014), Çetin ve Bıtırak (2015) tarafindan yapılan çalışmalarda elde edilen bulgular ile paralel sonuçlar içermektedir. Çalışmada elde edilen bir diğer bulgu, para arzı ile pay senedi getirisi arasındaki anlamlı ancak beklenenin aksine negatif yönlü ilişkinin varlığıdır. Para arzındaki \%1'lik değişim pay senedi getirisinde \%1,7689'luk azalışa sebep olmaktadır. Bu bulgu, Sevinç (2014) çalışmasında elde edilen bulgu ile benzerlik göstermektedir. Diğer taraftan çalışmada, altın fiyatı ve enflasyon oranı ile pay senedi getirisi arasında istatistiksel olarak anlamlı bir ilişki tespit edilmemiştir.

\section{SONUÇ, DEĞERLENDİRME VE ÖNERILER}

Rasyonel yatırımcılar gelişmekte olan ülkelerin pay senedi piyasalarında daha yüksek getiri imkânlarına sahip olabilmektedir. Bu açıdan hem yerli hem de yabancı yatırımcıların pay senedi getirilerini etkileyebilecek sistematik faktörlerin olası etkilerinden haberdar olmaları gerekmektedir. Böylelikle yatırımcılar daha etkin portföyler oluşturulabilmektedir. Bankaların kurumsallık, büyüklük ve karlılık gibi birçok faktör doğrultusunda diğer firmalara göre daha iyi ve güvenilir durumda olması, yatırımcıların bankaların pay senetlerine daha fazla talep göstermesine yol açabilmektedir. Dolayısıyla bankaların pay senedi getirilerine 
etki edebilecek makroekonomik faktörlerin belirlenmesi, hem yatırımcılar hem de mali sektörün lokomotifi konumunda olan bankalar açısından hayati öneme sahiptir.

Çalışmada, 2007: 12-2017: 9 dönemleri arasında pay senetleri BIST Banka Endeksi'nde işlem gören 13 bankanın pay senedi getirileri ile makroekonomik faktör olarak belirlenen altın fiyatı, döviz kuru, enflasyon oranı, faiz oranı ve para arzı arasındaki ilişkiyi panel veri analizi ile ortaya çıkarmak amaçlanmıştır. Panel veri analizini gerçekleştirebilmek için gerekli varsayımlar kapsamında ilk olarak bağımsız değişkenler arasında çoklu doğrusal bağlantının olup olmadığı, Spearman korelasyon analizi ve varyans şişirme faktör testi ile araştırılmıştır. Analizler neticesinde, değişkenler arasında çoklu doğrusal bağlantıya sebep olabilecek yüksek derecede ilişkiye rastlanmamıştır. Paneli oluşturan yatay kesitler arasında bağımlılık ise Pesaran CDlm (2004) testi ile sınanmış ve yatay kesit bağımlılığının varlığı tespit edilmiştir. Pesaran ve Yamagata (2008) delta testleri ile panel ve değişken bazında homojenlik sınaması yapılmıştır. Sınama sonucunda, panel ve değişken bazında eğim katsayılarının homojen olduğu belirlenmiştir. Panel veri analizi için temel varsayımlarından biri olan durağanlık ise panelde tespit edilen yatay kesit bağımlılı̆̆ 1 sorunu dikkate alınarak Smith vd. (2004) Boostrap ikincil nesil birim kök testi ile sınanmıştır. Birim kök testi sonrasında DOV, ENF, FAIZ ve PARZ değişkenlerine ilişkin serilerinin düzeyde durağan oldukları tespit edilmiştir. ALT değişkenine ait serinin ise birinci dereceden farkı alınarak durağanlık sağlanmıştır. Bağımlı değişken ile bağımsız değişkenler arasındaki ilişkinin ortaya çıkarılmasında hangi modelin kullanılacağı ise F testi ile belirlenmiştir. F testi sonucunda, modelin havuzlanmış model ile tahmin edilmesinin daha etkin sonuçlar vereceği tespit edilmiştir. Panel veri analizinde tutarlı ve doğru tahminleme gerçekleştirebilmek için serilerde otokorelasyon ve değişen varyans probleminin varlığı Breusch-Godfrey LM ve Harvey testleri ile analiz edilmiştir. Analizler neticesinde panelde otokorelasyon ve değişen varyans sorunlarının varlığ 1 ortaya çıkarılmıştır. Nihai tahminleme ise Pooled OLS doğrultusunda otokorelasyon ve değişen varyans sorunlarını dikkate alan White'ın yatay kesit kovaryans katsayısı yöntemi (White's cross section coefficient covariance method) ile standart hataların düzeltilmesi yoluyla gerçekleştirilmiştir.

Analiz sonucunda, döviz kuru ile pay senedi getirisi arasında istatistiksel olarak anlamlı ve beklenildiği gibi negatif ilişki tespit edilmiştir. Çalışmada elde edilen bu bulgu, Dizdarlar ve Derindere (2008), Sayılgan ve Süslü (2011), Kaya v.d. (2013), Yurttançıkmaz (2012) ve Belen ve Karamelikli (2016) tarafından gerçekleştirilen çalışmalarda elde edilen bulgular ile benzerlik göstermektedir. Döviz kurunda meydana gelen artış, pay senedi getirilerinde düşüşe neden olmaktadır. Diğer bir deyişle, bankaların pay senetlerine olan talebin artması ve ortalama getirinin yükselmesi için Türk Lirası'nın yabancı para karşısında değer kazanması gerekmektedir. Böylelikle yatırımcılar, sermaye piyasaları ile birlikte bankaların pay senetlerine daha fazla yatırım yapabilmektedir. Bu durum da bankaların pay senedi getirilerine olumlu yönde etki edebilmektedir. Döviz kuru ile pay senedi getirileri arasındaki negatif ilişkinin tespit edilmesi, ilgili otoritelerin pay piyasasında gerçekleşebilecek olası krizleri kontrol edebilmek için döviz kurlarını kullanabileceğini göstermektedir. Ayrıca gelişmekte olan ülke konumunda olan Türkiye, yabancı portföy yatırımlarını ülkeye çekebilmek için döviz kurları ile pay senedi getirileri arasındaki bu ilişkiyi kullanabilecektir. Türkiye'de yabancı yatırımın en fazla olduğu sektörlerden biri olan bankacılık sektöründe, yabancı sermayeli mevduat bankalarının bir hayli fazla oluşu da bu değerlendirmeyi desteklemektedir. 
Faiz oranı ile pay senedi getirisi arasında anlamlı ve beklenildiği gibi negatif ilişki belirlenmiştir. Ulaşılan bu bulgu, Boztosun (2010), Sevinç (2014), Çetin ve Bıtırak (2015) tarafından yapılan çalışmalarda elde edilen bulgular ile paralel sonuçlar içermektedir. Faiz oranlarının artması, yatırımcıların elinde bulundurdukları pay senetlerini satarak daha az riskli ve getirisi daha fazla olan tahvile yatırım yapmalarına yol açmaktadır. Bu durum pay senetlerinin değerlerini düşürmekte ve pay senedi getirilerini de olumsuz etkilemektedir. Dolayısıyla bankaların mevduat faiz oranlarındaki artış da yatırımcıları, riski daha yüksek olan pay senetleri yerine daha az riskli ve daha fazla getiriye sahip olan vadeli mevduata yönlendirmektedir. Çünkü rasyonel yatırımcıyı pay senedi yatırımına yönelten en önemli faktör, pay senedinden beklediği getirinin, faiz oranı getirisinden daha yüksek olmasıdır.

Para arzındaki artış toplam talebi yükseltebilmekte ve pay senedi getirilerini artırabilmektedir. Çalışmada, para arzı ile pay senedi getirisi arasındaki anlamlı ancak beklenenin aksine negatif yönlü ilişki tespit edilmiştir. Bu bulgu ise Sevinç (2014) çalışmasında elde edilen bulgu ile benzerlik göstermektedir. Dolayısıyla piyasada para arzının artması bankaların pay senedi getirilerini düşürmektedir. Diğer taraftan çalışmada, altın fiyatı ve enflasyon oranı ile pay senedi getirisi arasında istatistiksel olarak anlamlı bir ilişki tespit edilmemiştir. Borsa İstanbul Banka Endeksi'nde pay senetleri işlem gören bankalar, pay senedi getirilerini artırabilmek için döviz kurlarında, faiz oranlarında ve para arzında meydana gelebilecek değişimleri dikkate almalıdır. Yatırımcılar ise yerli paranın yabancı para karşısında değerinin düştüğü, faiz oranlarının yükseldiği ve para arzının arttığı dönemlerde bankaların pay senetlerine yatırım kararları alırken daha temkinli olmalıdır.

Çalışma, bankacılık sektöründe faaliyet gösteren diğer bankaların da analize dâhil edilmesi, inceleme döneminin genişletilmesi, farklı makroekonomik faktörlerin etkilerinin araştııılması ve farklı metodolojik yaklaşımların kullanılması suretiyle sonraki çalışmalarca geliştirilebilir.

\section{KAYNAKLAR}

Albayrak, Ali Sait (2005), "Çoklu Doğrusal Bağlantı Halinde Enküçük Kareler Tekniğinin Alternatifi Yanlı Tahmin Teknikleri ve Bir Uygulama", ZKÜ Sosyal Bilimler Dergisi, 1 (1), ss. 105-126.

Albeni, Mesut - Yusuf Demir (2005), "Makro Ekonomik Göstergelerin Mali Sektör Hisse Fiyatlarına Etkisi (İMKB Uygulamalı)”, Muğla Üniversitesi Sbe Dergisi, 14, ss. 1-18.

Baum, Christopher F. (2006), “An Introduction to Modern Econometrics Using Stata”, Stata Press: USA.

Beaulieu, Marie Claude - Cosset, Jean Claude - Essaddam, Naceur (2002), "The Impact of Political Risk on the Volatility of Stock Returns: the Case of Canada", Cahier de recherche/Working Paper, 2 (8), pp. 701-718.

Acar Boyacioğlu, Melek - Çürük, Derya (2016), "Döviz Kuru Değişimlerinin Pay senedi Getirisine Etkisi: Borsa İstanbul 100 Endeksi Üzerine Bir Uygulama", Muhasebe ve Finansman Dergisi, 70, ss.143-156. 
Boztosun, Derviş (2010), “İMKB’de İşlem Gören Banka Hisse Senetlerinin Getirileri İle Makro Ekonomik Faktörler Arasındaki İlişkinin Analizi”, 3. Sektör Sosyal Ekonomi Dergisi, 45 (4), ss. 39-53.

Chrystell Flota (2014), “The Impact of Exchange Rate Movements on Firm Value in Emerging Markets: The Case of Mexico”, American Journal of Economics, 4 (2A), pp. 51-72.

Çetin, Ali Cüneyt - Bıtırak, İbrahim Anıl (2015), “Türkiye'deki Makro Ekonomik Verilerin Pay senedi Getirilerini Etkileme Gücünün Arbitraj Fiyatlama Modeli İle Analizi”, Süleyman Demirel Üniversitesi Vizyoner Dergisi, 6 (12), ss. 1-19.

Dizdarlar, H. Işın - Derindere, Sinem (2008), "Pay senedi Endeksini Etkileyen Faktörler: İMKB 100 Endeksini Etkileyen Makroekonomik Göstergeler Üzerine Bir Araştırma”, Yönetim Dergisi, 61, ss. 113-124.

Errunza, Vihang R. - Senbed, Lemma B. (1981), “The Effects of International Operations on the Market Value of the Firm: Theory and Evidence”, The Journal Of Finance, 36 (2), pp. 401-417.

Gujarati, N. Damadoran (2003), “Basic Econometrics”, New York: McGraw Hill Book Co.

Gujarati, N. Damodar (1995), “Basic Econometrics”, 3rd Edition, New York: McGraw-Hill

Güngör, Bener - Yerdelen Kaygın, Ceyda (2015), "Dinamik Panel Veri Analizi İle Pay senedi Fiyatını Etkileyen Faktörlerin Belirlenmesi”, Kafkas Üniversitesi İktisadi ve İdari Bilimler Fakültesi Dergisi, 6 (9), ss. 149-168.

Humpe, Andreas - Macmillan, Peter (2007), “Can Macroeconomic Variables Expalin Long Term Stock Market Movements? A Comparisonof the Us and Japan”, Centre for Dynamic Macroeconomic Analysis Working Paper Series, 20 (7), pp. 1-26.

Belen, Muhammet - Karamelikli, Hüseyin (2016), “Türkiye’de Pay senedi Getirileri ile Döviz Kuru Arasındaki İlişkinin İncelenmesi: ARDL Yaklaşımı”, İstanbul Üniversitesi İşletme Fakültesi Dergisi, 45 (1), ss. 34-42.

Kaya, Vahdet - Çömlekçi, İstemi - Kara, Oğuz (2013), "Pay senedi Getirilerini Etkileyen Makroekonomik Değişkenler 2002-2012 Türkiye Örneği”, Dumlupınar Üniversitesi Sosyal Bilimler Dergisi, 35, ss. 167-176.

Korkmaz, Turhan - Y1ldız, Berk - Gökbulut, Rasim (2010), “Testing The Validity of CAPM in ISE National 100 İndex With Panel Data Analysis", İstanbul Üniversitesi İşletme Fakültesi Dergisi 39 (1), ss. 95-105.

Lesseig, Vance - Duane Stock (1998), “The Effect of Interest Rates on the Value of Corporate Assets and the Risk Premia of Corporate Debt”, Quantitative Finance and Accounting, 11 (5), pp. 5-22. 
Nisha, Nabila (2015), “Impact of Macroeconomic Variables on Stock Returns: Evidence from Bombay Stock Exchange (BSE)”, Journal of Investment and Management, 4 (5), pp. 162-170.

Özer, Ali - Kaya, Abdülkadir - Özer, Nevin (2011), "Pay senedi Fiyatları ile Makroekonomik Değişkenlerin Etkileşimi”, Dokuz Eylül Üniversitesi İktisadi ve İdari Bilimler Fakültesi Dergisi, 26 (1), ss. 163-182.

Palia, Darius - Thomas, Jacob (1997), “Exchange Rate Exposure and Firm Valuation: New Evidence for Market Efficiency" (http://faculty.som.yale.edu/jakethomas/papers/fx.pdf)

Say1lgan, Güven - Süslü, Cemil (2011), “Makroekonomik Faktörlerin Pay senedi Getirilerine Etkisi: Türkiye ve Gelişmekte Olan Piyasalar Üzerine Bir İnceleme”, BDDK Bankacilık ve Finansal Piyasalar Dergisi, 5 (1), ss. 73-96.

Sevinç, Erkan (2014), "Makroekonomik Değişkenlerin, BİST-30 Endeksinde İşlem Gören Pay senedi Getirileri Üzerindeki Etkilerinin Arbitraj Fiyatlama Modeli Kullanarak Belirlenmesi”, İstanbul Üniversitesi İşletme Fakültesi Dergisi, 43 (2), ss. 271-292.

Yurttançıkmaz, Ziya Çağlar (2012), "Döviz Kuru ve Enflasyonun Pay senedi Getirileri Üzerindeki Etkisi”, EKEV Akademi Dergisi, 16 (51), ss. 393-410. 
